\title{
CITRA PEREMPUAN DALAM PERIBAHASA JEPANG MENURUT NORMA DAN PANDANGAN ISLAM
}

\author{
Nani Sunarni \\ Program Studi Sastra Jepang, Fakultas Ilmu Budaya, Universitas Padjadjaran \\ nani.sunarni@unpad.ac.id \\ Eka Kurnia Firmansyah \\ Program Studi Sastra Arab, Fakultas Ilmu Budaya, Universitas Padjadjaran \\ eka.kurnia@unpad.ac.id
}

\begin{abstract}
Abstrak
Masyarakat umum memandang perempuan sebagai makhluk yang kuat tetapi sering pula dianggap makhluk yang lemah. Begitu pula dalam masyarakat Jepang, perempuan dianggap sebagai makhluk yang berpengaruh tetapi sebaliknya dapat pula dianggap makhluk yang lemah dan tidak memiliki pendirian. Hal tersebut, tercermin dalam peribahasa onna shichibu ni otoko sanbu (di lingkungan keluarga pengaruh ibu lebih kuat dari pada ayah) dan onna gokoro to aki no sora (perasaan perempuan mudah berubah-ubah/tidak memiliki pendirian). Kedua peribahasa tersebut hanya sebagai contoh dan masih banyak peribahasa lain yang mencerminkan citra dan identitas perempuan Jepang. Dalam konteks ini, Islam sebagai wahyu Ilahi, menempatkan perempuan pada posisi yang sangat terhormat dan mulia sesuai dengan kodrat dan tabiatnya, tidak berbeda dengan kaum laki-laki dalam masalah kemanusiaan dan hak-haknya. Oleh karena itu, tidak benar jika menilai ajaran Islam bersikap diskriminatif terhadap perempuan. Hal ini dapat dibuktikan dengan perbandingan pandangan budaya di luar Islam. Penelitian ini akan melihat citra perempuan dalam peribahasa Jepang menurut pandangan Islam. Penelitian ini menggunakan metode deskriptif kualitatif. Data yang digunakan berupa peribahasa Jepang yang di dalamnya terdapat kata onna (perempuan) dan dibatasi pada peribahasa yang menyatakan "kekuatan" yang diperbandingkan dengan pandangan Islam. Data dianalisis menggunakan pendekatan etnolinguistik Riley (2008).
\end{abstract}

Kata kunci: Jepang, onna, perempuan, peribahasa, Islam

\begin{abstract}
In general, society views that women are strong creatures but often also considered weak creatures. Likewise in Japanese society, Japanese women can be considered as influential creatures, but conversely it can also be considered creatures that are weak and have no stance. This is reflected in the proverb onna shichibu ni otoko sanbu (in a family environment the influence of the mother is stronger than that of the father) and onna gokoro to aki no sora (women's feelings change easily / have no position). Both of these proverbs are just examples and there are many other proverbs that reflect the image and identity of Japanese women. In this context, in fact Islam, whose norms are derived from the Divine revelation, has placed women in a very respectable and noble position in accordance with their nature and character, not unlike men in matters of humanity and their rights. Therefore, it is an assumption that is not true and is very wrong if there are those who consider that Islamic teachings are discriminatory towards women. Especially when compared with teachings, attitudes and customs outside of Islam. Therefore, this research is important to do. This research used descriptive qualitative method. The data used in the form of Japanese proverbs in which there is the word onna (female) and is limited to proverbs that state
\end{abstract}


"strength" and how is the view of Islam. Data were analyzed using the ethnolinguistic approach according to the view of Riley (2008).

Keywords: Japanese, onna, women, proverbs, Islam

\section{PENDAHULUAN}

"Perempuan sebagai tiang negara kalimat yang sering terdengar untuk penilaian perempuan di Indonesia. Tiang adalah bagian dari sebuah bangunan yang berfungsi sebagai penyangga bangunan tersebut. Kekuatan sebuah bangunan salah satunya ditentukan oleh kuat atau tidaknya tiang penyangga bangunan tersebut. Sejalan dengan kalimat di atas, negara diibaratkan sebagai bangunan dan perempuan diibaratkan sebagai tiangnya. Dengan demikian, kekuatan sebuah negara salah satunya ditentukan oleh kuatnya kaum perempuan dari negara tersebut. Kalimat tersebut sepadan dengan peribahasa dalam bahasa Jepang yang bermakna "Perempuan menjadi dasar kekuatan suatu Negara". Bila menyimak kedua kalimat di atas, begitu pentingnya perempuan sebagai bagian dari warga sebuah negara. Maju mundurnya suatu negara ditentukan oleh peran perempuan. Jepang sebuah negara di Asia yang memiliki tingkat perkonomian, pendidikan, keamanan, ketertiban, kebersihan yang tinggi. Keberhasilan ini, tidak terlepas dari peran perempuan Jepang khususnya perempuan Jepang sebagai ibu yang mampu dalam mengurus dan mendidik anak atau keluarganya. Pendidikan yang terkait dengan perempuan Jepang terkenal dengan istilah kyouiku mama (Benedict, 1979:277) .

Istilah kyouiku mama (教育ママ) terdiri atas dua kata yaitu kata kyouiku (教育) dan mama (ママ). Kyouiku (教育) terdiri atas dua huruf kanji yaitu '教 : kyou' atau dibaca pula oshieru' (mengajar) dan kanji '育 - iku atau dibaca 'sodateru, sodachi, sodatsu, hagukumu (membesarkan atau menumbuhkan) ( Toudou, 1987: 426). Secara harafiah kyouiku mama bermakna ibu pendidik. Kyouiku Mama merupakan konsep pemikiran kehidupan Jepang modern sebagai potret seorang ibu yang secara tegas dan disiplin dalam mendorong dan berupaya untuk mendukung anak agar berorientasi pada pendidikan baik pendidikan formal, nonformal, fisik, sosial, dan emosi. Perempuan Jepang setelah menikah walaupun telah mengdapatkan pendidikan tinggi rela menanggalkan kariernya untuk berhenti demi keluarga dan menjalankan kyouiku mama. Landasan pola pemikiran kolektif masyarakat Jepang sebagai budaya lokal tersebut tercermin dalam peribahasa bahasa Jepang. Oleh karena itu, penelitian ini bertujuan mendeskripsikan citra perempuan Jepang yang tercermin dalam peribahasa Jepang.

Islam memberikan kepada perempuan beberapa keistimewaan yang tidak dimiliki oleh laki-laki, dan memberikan peluang kepada para perempuan untuk aktif dalam berbagai bidang. Dalam al-Quran asal-usul dan kedudukan kaum wanita ditempatkan sejajar dengan kaum lelaki, baik dalam kapasitasnya sebagai abdi, maupun sebagai khalifah, keduanya mempunayai hak dan kewajiban yang seimbang derngan kodratnya masing-masing. Namun tidak berarti al-quran mengidentikan kaum laki laki dan wanita dalam segala hal, karena jika demikian malah menjadi tidak adil karena secaraa fisik (biologis). Dan psikologis keduanya mempunyai perbedaan secara alamiyah. 


\section{METODE PENELITIAN}

Artikel ini mengungkap citra perempuan Jepang yang tercermin dalam peribahasanya. Citra yang digunakan dalam penelitian ini adalah gambaran yang dimiliki orang banyak mengenai pribadi perempuan Jepang. Hal ini diadopsi dari definisi yang tercantum dalam kamus besar bahasa Indonesia (1995: 192) yaitu gambaran yang dimiliki orang banyak mengenai pribadi.

Metode yang digunakan yaitu metode deskriptif kualitatif. Dan data yang digunakan dalam penelitian ini adalah peribahasa Jepang yang di dalamnya terdapat kata onna (perempuan) yang bersumber dari kamus kotowaza (peribahasa) tahun 1990 serta bagaimanakah menurut pandangan ajaran Islam menurut Al-Qur'an dan Hadits.

Yang dimaksud peribahasa adalah kelompok kata atau kalimat yang tetap susunannya dan biasanya mengiaskan maksud tertentu atau ungkapan atau kalimatkalimat ringkas padhat, yang berisi perbandingan perumpamaan, nasihat, prinsip hidup atau aturan tingkah laku (KBBI, 1995: 755). Penelitian ini dilakukan secara bertahap, yaitu proses pengumpulan data, dilanjutkan ke proses analisis data dan proses interpretasi data, terakhir proses penarikan simpulan. Proses pengumpulan data dilakukan secara bertahap pula. Pertama dilakukan penyimakan terhadap sumber data. Dari proses ini teridentifikasi sebanyak 94 peribahasa yang di dalamnya terdapat kata onna (perempuan). Agar penelitian ini terfokus dilakukan reduksi data berdasarkan nilai positif dan negative dari 94 peribahasa tersebut. Hasil dari proses reduksi teridentifikasi 18 data yang memiliki nilai positif dan menunjukkan makna "sifat kuat" sebagai dasar kekuatan negara. Dari data yang terkoleksi, diklasifikasi berdasarkan peran dan yang mendukung peran perempuan tersebat sebagai dasar kekuatan negara. Selanjutnya dilakukan proses analisis data. Dalam proses ini, teridentifikasi satu data yang bermakna tentang peran onna (perempuan) sebagai dasar kekuatan negara (Jepang). Selanjutnya dilakukan identifikasi data yang menyatakan sifat atau karakter dari perempuan Jepang dan terkumpul sebanyak 9 data, menyatakan regulasi 1 data, pentingnya eksistensi perempuan 3 data, fungsi ibu 2 data, dan yang menyatakan "gaya penampilan" perempuan Jepang tiga data. Kelompok peribahasa ini dijadikan pendukung terhadap peribahasa yang menyatakan peran onna (perempuan) seperti telah disebutkan di atas. Lalu setelah mengidentifikasi data, selanjutnya penulis menjelaskan hubungan dan kontradiksi yang ada pada ajaran Islam.

\section{HASIL DAN PEMBAHASAN}

\subsection{Perempuan dalam Peribahasa Jepang}

Rasulullah Saw bersabda: "Sesungguhnya kaum perempuan setara dengan kaum laki-laki" (HR Imam Ahmad, Abu dawud, Al-Darimi, dan Ibn Majah). Istilah setara merujuk pada kesetaraan gender, bahwa tidak ada perbedaan antara laki-laki dan perempuan dalam kehidupannya. Bahkan seperti yang tertulis di atas bahwa perempuan dapat memegang peranan penting dalam keluarga dan negara. Peranan perempuan sebagai representasi praktik kehidupan perempuan Jepang yang menyentuh hingga ke ranah pengetahuan tradisional dan ekspresi budaya tradisional tercermin dalam peribahasa Jepang. Pemeliharaan nilai-nilai kearifan lokal dalam peribahasa tersebut berorientasi pada pandangan hidup yang diwujudkan dalam 
tindakan-tindakan konkrit peran perempuan Jepang dalam mewujudkan bangsa yang bermartabat dan mampu menjadikan bangsa yang unggul khususnya di Asia. Pemeliharaan dan eksplorasi menyangkut pengetahuan tradisional masyarakat, perilaku masyarakat, maupun budaya menunjukkan identitas dari perempuan Jepang sebagai bagian dari masyarakat Jepang.

Menurut pandangan budaya, identitas lekat dengan tanda-tanda kebahasaan, keyakinan, sikap, gaya hidup, cara berpikir dan berperilaku masyarakat tersebut. Peribahasa Jepang merupakan bentuk representasi kultural hasil dari pemikiran kolektif masyarakat Jepang. Perempuan Jepang sering menjadi kaum marjinal di bawah kaum laki-laki. Namun, dalam peribahasa pun terdapat nilai-nilai kekuatan bagi perempuan Jepang sebagai identitas perempuan Jepang tang mampu mendukung perkembangan dan kemajuan Jepang. Masyarakat Jepang dalam pemahaman atas peribahasa sebagai produk budayanya berhubungan dengan bagaimana produk-produk tersebut diciptakan, dikonsumsi, dan dipraktikan dalam kehidupannya yang terikat dengan regulasi. Untuk mermaknai budaya perlu mempertimbangkan hubungan antara unsur-unsur budaya yang menjadi kesatuan budaya tersebut, yaitu dengan mempertimbangkan makna kultural dari produksi, konsumsi, regulasi, representasi, dan identitas. Dalam hal ini, hubungan tersebut mengandung makna bahwa peribahasa Jepang sebagai kearifan lokal: (1) diproduksi dari pengetahuan kolektif masyarakat Jepang dan diikat dalam pola hidup masyarakat Jepang, (2) dipahami berdasarkan cara masyarakat Jepang menjalankan praktik kesehariannya dalam ikatan pola hubungan, serta (3) membentuk dan menunjukkan identitas-identitas bermakna dalam setiap peribahasa.

Lokalitas, termasuk di dalamnya menyangkut nilai-nilai kearifan lokal dalam peribahasa Jepang hasil dari produk masa lalu yang terus diberdayakan hingga sekarang ini. Pendekatan kajian budaya digunakan untuk mengidentifikasi makna mulai dari level produksi (penciptaan makna), representasi (produk budaya dalam praktik wacana), identitas (subjek budaya), konsumsi (penerimaan makna), dan regulasi (kebijakan menyangkut produk budaya). Nilai-nilai kearifan lokal yang tercermin dalam peribahasa Jepang sebagai kearifal lokal masih mampu diterapkan dalam konteks kekinian yang terwujud dan dapat dimaknai dalam hubungannya dengan peran, syarat, dan fungsinya.

Peribahasa yang menyatakan peran perempuan Jepang sebagai dasar kekuatan Jepang tercerrmin dalam peribahasa berbunyi onna wa kuni no tairage 'Perempuan menjadi dasar kekuatan suatu Negara'. Masyarakat Jepang menjustifikasi begitu kuatnya peran perempuan bagi negaranya. Kekuatan Jepang ditentukan oleh bangsa Jepang sendiri. Dan yang menjadikan kuatnya bangsa Jepang salah satunya yaitu peran perempuan Jepang terutama dalam mendidik dan membesarkan anaknya untuk menciptakan generasi penerus bangsa. Bagi masyarakat Jepang pendidikan anak umumnya diserahkan kepada ibunya. Oleh karena itu, hal tersebut dikenal dengan istilah kyouiku mama. Sedangkan ayah berperan dalam memenuhi kebutuhan secara finansial, walaupun dalam waktu-waktu libur besar tertentu, ayah pun berusaha untuk menemani keluarganya. Misalnya pada waktu acara libur undokai (pesta olah raga), ohanami (pesta menikmati keindahan bunga), oshougatsu (tahun baru) dan lain-lain. Dengan peran istri atau ibu dalam mendidik anaknya, diperlukan perempuan Jepang yang berkarakter kuat. Sehingga kekuatan perempuan Jepang 
sebagai pendukung "perempuan sebagai dasar negara" tercermin dalam peribahasaperibahasa berikut.

Tabel 1: Karakter Perempuan Jepang yang tercermin dalam Peribahasa

\begin{tabular}{|c|c|c|c|c|}
\hline No & Peribahasa & Cara baca & Makna Denotatif & $\begin{array}{c}\text { Makna } \\
\text { Peribahasa }\end{array}$ \\
\hline 1 & $\begin{array}{l}\text { 女に五障三従あ } \\
\text { り }\end{array}$ & $\begin{array}{l}\text { Onna ni } \\
\text { goshousan juu ari }\end{array}$ & $\begin{array}{l}\text { Ada } 5 \text { halangan dan } 3 \text { hal } \\
\text { yang harus ditaati } \\
\text { perempuan }\end{array}$ & Ketat aturan \\
\hline 2 & 女に七去あり & $\begin{array}{l}\text { Onna ni sichikyo } \\
\text { ari }\end{array}$ & $\begin{array}{l}\text { Ada } 7 \text { kali berlalu dari } \\
\text { perempuan }\end{array}$ & kuat \\
\hline 3 & $\begin{array}{l}\text { 女の一念岩をも } \\
\text { 徹す }\end{array}$ & $\begin{array}{l}\text { Onna no ichinen } \\
\text { iwa o mo toosu }\end{array}$ & $\begin{array}{l}\text { Niat perempuan akan } \\
\text { menghancurkan cadas }\end{array}$ & $\begin{array}{l}\text { Memiliki } \\
\text { keinginan yang } \\
\text { sangat kuat } \\
\text { tajam }\end{array}$ \\
\hline 4 & 女の心は猫の眼 & $\begin{array}{l}\text { Onna no kokoro } \\
\text { wa neko no me }\end{array}$ & $\begin{array}{l}\text { Hati perempuan itu sama } \\
\text { dengan mata kucing }\end{array}$ & \\
\hline 5 & $\begin{array}{l}\text { 女の商談と七の } \\
\text { 段は割り切れず }\end{array}$ & $\begin{array}{l}\text { Onna no shoudan } \\
\text { to shichi no dan } \\
\text { wa warikirezu }\end{array}$ & $\begin{array}{l}\text { Negosiasi dagang } \\
\text { perempuan dan } 7 \text { tingkat } \\
\text { tidak bisa habis dibagi }\end{array}$ & Ulet \\
\hline & $\begin{array}{l}\text { 女は敷居を跨ぎ } \\
\text { ながらも七十企 } \\
\text { み }\end{array}$ & $\begin{array}{l}\text { Onna wa shikii o } \\
\text { mataginagara mo } \\
\text { shichijuu } \\
\text { takurami }\end{array}$ & $\begin{array}{l}\text { Sambil melangkahi } \\
\text { gerbang pintu, } \\
\text { pikirannya akan berputar } \\
\text { tujuh puluh kali }\end{array}$ & Teliti \\
\hline 7 & $\begin{array}{l}\text { 女は人間を左右 } \\
\text { にせよ }\end{array}$ & $\begin{array}{l}\text { Onna wa hitoai o } \\
\text { sayuu nio seyo }\end{array}$ & $\begin{array}{l}\text { Pertempuan akan } \\
\text { mempengaruhi manusia }\end{array}$ & Berpengaruh \\
\hline 8 & $\begin{array}{l}\text { 女は人月四十五 } \\
\text { 日あり }\end{array}$ & $\begin{array}{l}\text { Onna wa } \\
\text { hitotsukishijuu } \\
\text { gonichi ari }\end{array}$ & $\begin{array}{l}\text { Bagi perempuan sebulan } \\
\text { adalah } 45 \text { hari }\end{array}$ & $\begin{array}{l}\text { Sibuk, cekatan, } \\
\text { pandai } \\
\text { menggunakan } \\
\text { waktu }\end{array}$ \\
\hline 9 & $\begin{array}{l}\text { 女は己れを喜ぶ } \\
\text { 者の為に容る }\end{array}$ & $\begin{array}{l}\text { Onna wa onore } \\
\text { o yorokobu } \\
\text { mono no tameni } \\
\text { yoru }\end{array}$ & $\begin{array}{l}\text { Perempuan itu ada demi } \\
\text { orang yang senangn } \\
\text { dengan dirinya }\end{array}$ & $\begin{array}{l}\text { Berbakti kepada } \\
\text { orang yang } \\
\text { menyayanginya }\end{array}$ \\
\hline
\end{tabular}

Untuk menjadi perempuan sebagai dasar kekuatan negara selain memiliki karakter atau sifat seperti tercermin dalam peribahasa di atas, terdapat persyaratan sebagai regulasi dalam budayanya. Persyaratan tersebut tercermin dalam peribahasa sebagai berikut. 
Tabel 2: Regulasi yang Tercermin dalam Peribahasa Bahasa Jepang

\begin{tabular}{clll}
\hline Peribahasa & \multicolumn{1}{c}{ Cara baca } & Makna Denotatif & \multicolumn{1}{c}{ Makna Peribahasa } \\
\hline $\begin{array}{c}\text { 女は弱しされ } \\
\text { よ゙母は強し }\end{array}$ & $\begin{array}{l}\text { Onna wa yowashi } \\
\text { keredo haha wa } \\
\text { chuyoshi }\end{array}$ & $\begin{array}{l}\text { Perempuan itu } \\
\text { lemah, tetapi ibu } \\
\text { itu kuat. }\end{array}$ & $\begin{array}{l}\text { Sebelum menjadi ibu, } \\
\text { perempuan itu akan berada } \\
\text { dalam posisi lemah }\end{array}$ \\
\hline
\end{tabular}

Dalam peribahasa di atas, terdapat kata onna (perempuan) dan haha (ibu) dari kedua istilah tersebut memiliki rujukan yang sama yaitu perempuan atau wanita. Dalam kamus besar bahasa Indonesia (KBBI, 1995:753) disebutkan bahwa perempuan adalah orang (manusia) yang mempunyai puki, dapat menstruasi, hamil, melahirkan anak, dan menyusui. Sedangkan ibu adalah orang perempuan yang telah melahirkan seseorang anak atau sebutan wanita yang sudah bersuami (KBBI, 1995: 364). Dari definisi di atas terdapat perbedaan yaitu onna (perempuan) merujuk pada sifat yaitu manusia yang melahirkan anak, sedangkan ibu orang perempuan yang telah melahirkan anak. Dengan demikian, onna (perempuan) belum tentu melahirkan anak, namun ibu pasti melahirkan anak. Oleh karena itu terdapat perbedaan peran dari keduanya. Dengan kata lain, perempuan belum tentu menjadi ibu, namun ibu pasti perempuan. Bila kita memandang peribahasa di atas, untuk menjadi perempuan yang kuat perlu "menikah". Karena dengan "menikah" bagi masyarakat Jepang konvensional "fungsi utama perempuan" dapat terwujud, yaitu dapat menjalankan perannya sebagai kyouiku mama sebagai pencipta generasi-generasi yang kuat. Generasi kuat dapat menjadikan negara kuat, sebaliknya generasi lemah-negara pun akan lemah yang dimungkinkan akan terjadi kehancuran. Dengan demikian, begitu pentingnya "ibu" bagi keluarga di Jepang. Sehingga eksistensi atau keberadaan perempuan pun tercermin dalam peribahasa berikut.

Tabel 3: Eksistensi Perempuan yang tercermin dalam Peribahasa Bahasa Jepang

\begin{tabular}{|c|c|c|c|c|}
\hline No & Peribahasa & Cara baca & Makna & Keterangan \\
\hline 1 & $\begin{array}{l}\text { 女の足駄にて作 } \\
\text { れる笛には秋の } \\
\text { 鹿寄る }\end{array}$ & $\begin{array}{l}\text { Onna no ashida } \\
\text { nite tsukureru fue } \\
\text { ni wa aki no shika } \\
\text { yoru }\end{array}$ & $\begin{array}{l}\text { Rusa musim gugur } \\
\text { akan mendekat pada } \\
\text { bunyi seruling yang } \\
\text { terbuat dari kaus kaki } \\
\text { perempuan }\end{array}$ & $\begin{array}{l}\text { Walaupun jelek } \\
\text { perempuan tetap } \\
\text { diperlukan }\end{array}$ \\
\hline 2 & $\begin{array}{l}\text { 女の手から物を } \\
\text { とった出家は五 } \\
\text { 百生の間手のな } \\
\text { い者に生まれる }\end{array}$ & $\begin{array}{l}\text { Onna no te kara } \\
\text { mono o totta } \\
\text { shutsuke wa } \\
\text { gohyakushou no } \\
\text { aidate no nai } \\
\text { mono ni umareru }\end{array}$ & $\begin{array}{l}\text { Pendeta yang } \\
\text { mengambil sesuatu } \\
\text { dari perempuan, akan } \\
\text { terlahir kembali } \\
\text { sebagai orang tak } \\
\text { berlengan sebanyak } \\
500 x\end{array}$ & $\begin{array}{l}\text { Perempuan itu } \\
\text { harus dipusti-pusti } \\
\text { tidak boleh disakiti }\end{array}$ \\
\hline 3 & $\begin{array}{l}\text { 女は氏無くて玉 } \\
\text { の輿に乗る }\end{array}$ & $\begin{array}{l}\text { Onna wa } \\
\text { ujinakute tama } \\
\text { no koshi ni noru }\end{array}$ & $\begin{array}{l}\text { Perempuan itu } \\
\text { meskipun tak punya } \\
\text { nama bisa naik tandu }\end{array}$ & $\begin{array}{l}\text { Wanita itu } \\
\text { walaupun tidak } \\
\text { terkenal namun } \\
\text { dapat beruntung }\end{array}$ \\
\hline
\end{tabular}


Pentingnya peran ibu dalam budaya masyarakat Jepang, karena ada regulasi bahwa seorang ibu adalah perempuan yang melahirkan perempuan calon ibu. Dan keberhasilan calon ibu merupakan hasil dari asuhan seorang ibu. Bahkan terdapat kalimat "ibu dekat dengan anak gadisnya". Pemikiran masyarakat Jepang tersebut ditunjukkan dalam peribahasa berikut.

Tabel 4: Fungsi Ibu yang tercermin Dalam Peribahasa Bahasa Jepang

\begin{tabular}{cccll}
\hline No & Peribahasa & Cara baca & $\begin{array}{c}\text { Makna } \\
\text { Denotatif }\end{array}$ & Makna Peribahasa \\
\hline 1 & 女は女同士 & $\begin{array}{l}\text { Onna wa onna } \\
\text { doushi }\end{array}$ & $\begin{array}{l}\text { Perempuan } \\
\text { harus dengan } \\
\text { perempuan }\end{array}$ & $\begin{array}{l}\text { Perempuan harus dengan } \\
\text { perempuan }\end{array}$ \\
2 & $\begin{array}{l}\text { 女は母親の育て } \\
\text { 柄 }\end{array}$ & $\begin{array}{l}\text { Onna wa haha } \\
\text { oya no sodategara }\end{array}$ & $\begin{array}{l}\text { Perempuan } \\
\text { terbentuk atas } \\
\text { asuhan ibunya }\end{array}$ & $\begin{array}{l}\text { Perempuan terbentuk atas } \\
\text { asuhan ibunya }\end{array}$ \\
\hline
\end{tabular}

Karena perempuan sebagai ibu merupakan pendidik, tauladan, dan cermin bagi anaknya dan keluarganya, maka ibu harus menjadi contoh dan menjaga penampilan, seperti dalam peribahasa berikut.

Tabel 5: "Penampilan" Perempuan Jepang yang tercermin Dalam Peribahasanya

\begin{tabular}{|c|c|c|c|c|}
\hline No & Peribahasa & Cara baca & Makna Denotatif & Makna Peribahasa \\
\hline 1 & 女は衣装髪形 & $\begin{array}{l}\text { Onna wa ishou } \\
\text { kami katachi }\end{array}$ & $\begin{array}{l}\text { Perempuan tercermin } \\
\text { dari pakaian dan } \\
\text { rambutnya }\end{array}$ & Harus selalu rapi \\
\hline 2 & 女は会釈に余れ & $\begin{array}{l}\text { Onna wa eshaku } \\
\text { ni amare }\end{array}$ & $\begin{array}{l}\text { Perempuan itu harus } \\
\text { banyak basa-basi }\end{array}$ & $\begin{array}{l}\text { Harus bersikap } \\
\text { sederhana }\end{array}$ \\
\hline 3 & $\begin{array}{l}\text { 女は=髪形 }\{= \\
\text { 髪頭 }\}\end{array}$ & $\begin{array}{l}\text { Onna wa }= \\
\text { kamikatachi } \\
\{=\text { kamikashira\} }\end{array}$ & $\begin{array}{l}\text { Perempuan itu } \\
\text { dicerminkan oleh } \\
\text { rambutnya }\end{array}$ & $\begin{array}{l}\text { Harus menjaga } \\
\text { penampilan }\end{array}$ \\
\hline
\end{tabular}

\subsection{Citra Perempuan Jepang Yang Tercermin Dalam Peribahasanya Menurut Norma dan Pandangan Islam}

Terkait karakter perempuan yang tercermin dalam peribahasa Jepang女に五障 三従あり(Onna ni goshousan juu ari) yang bermakna bahwa perempuan harus ketat aturan, menurut norma dan pandangan Islam disebutkan bahwa wanita juga memiliki aturan, fungsi dan peran. Aturan, fungsi dan peran ini tentu saja berbeda dengan aturan, fungsi dan peran laki-laki. Dalam hal ini fungsi agama telah mengaturnya. Perbedaan ini bukan berarti adanya diskriminasi yang dilakukan islam atau berniat merendahkan wanita. Fungsi dan peran ini tentu sama sebagaimana tujuan hidup manusia serta dipertimbangkan sesuai dengan potensi yang dimiliki 
wanita. Berikut adalah kewajiban dan aturan wanita dalam Islam, sebagaimana aturan, fungsi dan peran nya dalam pandangan Islam.

1. Aturan kewajiban sebagai hamba Allah

Kewajiban utama wanita sebagai manusia tentu adalah mengabdi dan menyembah hanya kepada Allah SWT. Tidak ada satupun yang berhak diikuti perkataan, perintahnya selain dari yang telah Allah perintahkan. Kecintaan dan pengabdian wanita terhadap suaminya, terhadap ibunya, terhadap keluarganya, tentu tidak boleh melebihi terhadap Allah. Bahkan, jikapun mengikuti perkataan suami, orang tua, atau keluarga itu semua dalam kerangka mengikuti perintah Allah SWT.

Hal ini sebagaimana disampaikan dalam Al-Quran bahwa manusia senantiasa harus mengikuti dan taat kepada Allah SWT. "Sesunguhnya Kami menurunkan kepadamu Kitab (Al Quran) dengan (membawa) kebenaran. Maka sembahlah Allah dengan memurnikan ketaatan kepada-Nya". (QS Az Zumar : 2)

2. Aturan kewajiban sebagai istri bagi suami

Dalam keluarga hakikatnya, wanita adalah istri bagi suaminya. Sebagai seorang istri, wanita memiliki kewajiban untuk dapat bekerja sama dan menjalankan rumah tangga dengan baik dengan suami. Begitupun sebetulnya dengan suami. Seorang istri yang baik, ia harus dapat memberikan kebahagiaan dan juga membantu suaminya dalam menjalankan rumah tangga. Tugas utama seorang suami adalah mencari nafkah sedangkan istrinya adalah pengelolanya di rumah dan menjaga amanat tersebut dari suaminya.

Kewajiban istri meliputi berbagai hal mulai dari pemenuhan kebutuhan seksual dari suami, mengelola aset rumah tangga, menjaga amanat harta dari suami, membangun pendidikan anak-anak, dan saling support dengan suami untuk dapat meemenuhi kebutuhan rumah tangga.

3. Kewajiban sebagai ibu bagi anak-anak.

Kewajiban wanita juga bisa sebagai ibu bagi anak-anaknya. Selain dari sebagai anak dari orang tuanya, seorang wanita juga berkewjiban untuk mendidik anak-anaknya dengan baik. Pada hakikatnya, anak-anak adalah titipan dari Allah yang harus dididik dan kelak mereka harus meneruskan misi khalifah fil ard di bumi ini, meneruskan apa yang telah orang tuanya berikan dan titipkan.

4. Aturan kewajiban sebagai khalifah fi al-Ardli

"Ingatlah ketika Tuhanmu berfirman kepada para Malaikat: "Sesungguhnya Aku hendak menjadikan seorang khalifah di muka bumi." Mereka berkata: "Mengapa Engkau hendak menjadikan (khalifah) di bumi itu orang yang akan membuat kerusakan padanya dan menumpahkan darah, padahal kami senantiasa bertasbih dengan memuji Engkau dan mensucikan Engkau?" Tuhan berfirman: "Sesungguhnya Aku mengetahui apa yang tidak kamu ketahui" (QS Al Baqarah : 30)

Di ayat tersebut, dijelaskan bahwa tugas manusia adalah sebagai khalifah fi alArdli. Untuk itu, tugas-tugas wanita secara keseluruhan semuanya harus mengarah pada menjalankan peran tersebut. Sebagai ibu, pekerja, atau pun istri ia harus menjalankannya dalam rangka menjalankan kewajiban khalifah $f i$ 
al-Ardli. khalifah fi al-Ardli pada hakikatnya adalah memberikan kemaslahatan umat manusia di bumi, memberikan kemakmuran, melestarikan kehidupan lebih baik di mulai dari dirinya, keluarga, masyarakat, dan seluruh umat manusia yang ada di muka bumi. Hakikat Penciptaan Manusia menurut Pandangan Islam ini lah yang akhirnya menjadi kewajiban pula bagi manusia.

5. Tanggung jawab terhadap lingkungan dan masyarakat.

Tanggung jawab wanita juga terhadap lingkungan dan masyarakatnya. Wanita yang memiliki potensi lebih, maka ia pun dapat membantu lingkungan atau masyarakatnya agar dapat maju bersama sama. Wanita yang memiliki kelebihan dan kemampuan maka bisa memberikan atau menyebarkannya kepada lingkungan sekitarnya. Pada hakikatnya kewajiban wanita bukan hanya terhadap diri dan keluarganya saja, melainkan kepada seluruh elemen yang meliputi fungsi dan peran dirinya, sebagaimana Allah telah memberikan potensi tersebut kepada diri wanita.

Terkait karakter perempuan yang tercermin dalam peribahasa Jepang女に七去 あり(Onna ni sichikyo ari) yang bermakna bahwa perempuan harus kuat, menurut norma dan pandangan Islam disebutkan bahwa wanita juga memang harus kuat baik secara mental maupun spiritual.

Sejak zaman nabi, perempuan punya peranan besar dalam kehidupan. Mereka sangatlah kuat dan bahkan dijadikan panutan bagi banyak orang karena pengalaman hidupnya menyentuh. Sejak dulu tugas perempuan juga sudah berat, tidak kalah dari kaum Adam. Tak hanya baik dalam budi pekerti, perempuan di zaman nabi juga wajib dihormati derajatnya. Bahkan perempuan oleh Allah SWT dijadikan tamsil atau contoh teladan, yang disebutkan dalam Alquran. Bukan saja teladan yang baik, mereka yang kerap bersikap buruk pun dituliskan kisahnya dalam kitab suci umat Islam tersebut.

Berikut adalah contoh perempuan-perempuan hebat dan kuat yang disebutkan dalam Alquran :

1. Maryam

Perempuan yang dikenal sebagai ibunda Nabi Isa ini paling sering disebut di dalam Alquran. Bahkan menjadi nama salah satu surat dalam kitab suci, yaitu Surat Maryam. Bukan di situ saja, kisah hidup Maryam yang bikin orang lain takjub itu juga tertulis di dalam Surat Al-Imran, Surat Al-Baqarah, An-Nisaa, Al-Ma'idah, At-Taubah, Al-Mu'minun, Al-Ahzab, Al-Hadid, AsSaff, dan Surat at-Tahrim.

Maryam sangatlah kuat tatkala dihina dan bahkan difitnah dikarenakan mengandung Nabi Isa tanpa ada seorang ayah, beliau difitnah telah melakukan perbuatan zina atas kehamilannya.

Firman Allah Swt :

"(ingatlah) Maryam binti Imran yang memelihara kehormatannya, maka Kami tiupkan ke dalam rahimnya sebagian dari ruh (ciptaan) Kami. Dan Dia membenarkan kalimat Rabbnya dan kitab-kitab-Nya, dan Dia adalah Termasuk orang-orang yang taat" (QS At-Tahrim: 12)

2. Zulaikha 
Zulaikha sering menjadi ikon asmara dalam kisah-kisah cinta. Misalnya kisah asmaranya dengan Nabi Yusuf yang ganteng. Alquran menceritakan bahwa cinta adalah anugerah Allah. Tetapi agama mengatur cara bercinta yang sesuai tuntunan, yaitu melalui akad nikah yang sah.

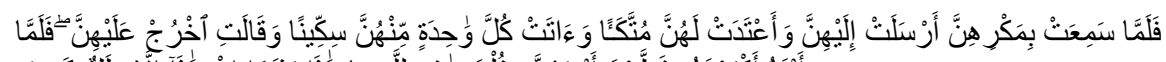

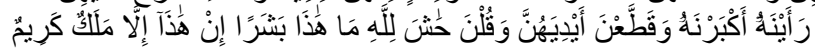

Maka tatkala wanita itu (Zulaikha) mendengar cercaan mereka, diundangnyalah wanita-wanita itu dan disediakannya bagi mereka tempat duduk. Dan diberikannya kepada masing-masing mereka sebuah pisau (untuk memotong jamuan). Kemudian dia berkata (kepada Yusuf):

"Keluarlah (nampakkanlah dirimu) kepada mereka".

Maka tatkala wanita-wanita itu melihatnya, mereka kagum kepada (keelokan rupanya). Dan mereka melukai (jari) tangannya dan berkata: "Maha sempurna Allah SWT, ini bukanlah manusia. Sesungguhnya ini tidak lain hanyalah malaikat yang mulia". (Yusuf 12:31)

3. Ratu Bilqis

Ratu Bilqis adalah seorang ratu cantik jelita di Negeri Saba', akan tetapi berhasil ditaklukkan oleh Nabi Sure, lalu masuk Islam.

(29)

Berkata ia (Balqis) "Hai pembesar-pembesar, sesungguhnya telah dijatuhkan kepadaku sebuah surat yang mulia."

Terkait penampilan perempuan yang tercermin dalam peribahasa Jepang女は 衣装髪形 (Onna wa ishou kami katachi) yang bermakna bahwa perempuan harus selalu rapi，女は会釈に余れ (Onna wa eshaku ni amare) yang bermakna bahwa perempuan harus berpenampilan sederhana, dan peribahasa女は=髪形 $\{=$ 髪頭 $\}$ (Onna wa= kamikatachi \{=kamikashira\}) yang bermakna bahwa perempuan harus menjaga penampilannya yang dicerminkan oleh rambutnya.menurut norma dan pandangan Islam disebutkan bahwa wanita juga memang harus selalu menjaga penampilan.

Islam memandu perempuan untuk berlaku santun, baik santun dalam penampilan, berpakaian maupun bertingkah laku. Oleh karena itu, perempuan didorong untuk melepaskan diri dari jebakan tabarruj yang artinya menampakkan hal yang seharusnya tertutup di hadapan laki-laki yang bukan muhrimnya.

Perbuatan itu meliputi menampakkan perhiasan yang dipakainya dan bagianbagian dari diri perempuan yang menawan hati orang lain. Dalam pandangan Syekh al-Maududi, jika dikaitkan dengan perempuan, tabarruj berarti menampakkan keelokan wajah dan bagian tubuh yang membangkitkan berahi di hadapan laki-laki bukan muhrim. Makna lainnya adalah memamerkan pakaian dan perhiasan yang indah serta memamerkan diri dan jalan berlenggak-lenggok di hadapan laki-laki yang bukan muhrim. Haya dalam bukunya, Ensiklopedi Wanita Muslimah, menuturkan berdasarkan kesepakatan para ulama, tabarruj merupakan perbuatan yang diharamkan. 
Seperti diungkapkan di atas, menurut ulama ternama Yusuf Al-Qaradhawi, tabarruj ini mempunyai corak beragam yang sudah dikenal sejak zaman dahulu hingga sekarang. Ia menjelaskan, ada perilaku perempuan Muslim yang membuatnya terlepas dari jerat tabarruj, dengan kata lain, mereka selalu dalam koridor santun menurut Islam.

Mereka selalu menahan pandangannya. Sebab, perhiasan perempuan yang paling mahal adalah rasa malu. Bentuk malu yang lebih tegas adalah "menahan pandangan,". Mereka juga mampu mengendalikan diri untuk tak bergaul secara bebas antara laki-laki dan perempuan.

Pakaian yang dikenakan perempuan Muslim, harus sesuai dengan tata kesopanan Islam. Pakaian tersebut menutup seluruh tubuh, kecuali wajah dan kedua telapak tangan. Hal lain yang perlu mendapatkan perhatian, pakaian itu tak tipis serta tidak membentuk lekukan tubuh. Mengenai hal ini, Rasulullah menyatakan perempuan-perempuan ahli neraka adalah yang berpakaian, tetapi telanjang, yang condong pada maksiat dan menarik orang lain berbuat maksiat. Al-Qaradhawi menjelaskan, maksud berpakaian, tetapi telanjang adalah pakaian mereka tak berfungsi menutup aurat.

Aisyah pernah mengingatkan perempuan yang berpakaian semacam itu. Saat itu beberapa orang dari Bani Tamim masuk ke rumah Aisyah dengan berpakaian tipis. Lalu, Aisyah berkata, "Kalau kalian orang Mukmin, maka bukan seperti itu pakaian seorang perempuan Mukmin," katanya.

Selanjutya dalam berpenampilan harus senantiasa khusyuk dan bersahaja baik dalam berbicara, cara berjalan, menjauhkan gerak-gerik yang tak baik, pun menuntun perempuan Muslim dari kubangan tabarruj. Al-Qaradhawi menuturkan, gerakan yang dibuat-buat, termasuk perbuatan yang biasa dilakukan perempuan nakal, bukan budi pekerti perempuan Muslim.

Terkait pentingnya eksistensi perempuan yang tercermin dalam peribahasa Jepang女の手から物をとった出家は五百生の間手のない者に生まれる(Onna no te kara mono o totta shutsuke wa gohyakushou no aidate no nai mono ni umareru) yang bermakna bahwa perempuan itu harus dipusti-pusti tidak boleh disakiti, maka menurut norma dan pandangan Islam disebutkan bahwa perempuan adalah makhluk yang unik dan istimewa. Sungguh, ia sangat dimuliakan dalam Islam. Bahkan dalam Al-Qur'an banyak menjelaskan hukum yang dikhususkan untuk perempuan, hal ini bukan dikarenakan kaum perempuan itu lemah dan banyak kekurangan, melainkan karena Allah sangat peduli dan sayang pada perempuan yang beriman.

Dari Abdullah bin 'Amr Radhiallahu 'Anhuma bahwa Rasulullah Shalallahu "Alaihiwassalam bersabda: "Dunia ini adalah perhiasan/kesenangan dan sebaik-baik perhiasan/kesenangan dunia adalah wanita yang sholihah." (HR. Muslim,Nasa'i, Ibnu Majah dan Ahmad)

Dalam lafazh lain: "Sesungguhnya dunia ini adalah perhiasan dan tidak ada di antara perhiasan dunia yang lebih baik daripada wanita yang sholihah." (HR. Ibnu Majah), maka defenisi wanita sholihah dalam pandangan Islam adalah sebagaimana dalam firman-Nya: "Maka wanita yang sholeh, ialah yang taat kepada Allah lagi memelihara diri ketika suaminya tidak ada, oleh karena Allah telah memelihara (mereka)" (QS. an-Nisa':34)

Islam tidak pernah mengajarkan umatnya untuk berbuat kasar kepada wanita. Seorang wanita memiliki perasaan yang lembut dan sangat mudah tersentuh. 
Sedikit saja mereka disakiti maka mereka akan sakit hati. Maka itu, wanita harus diperlakukan secara baik. Apabila wanita melakukan kesalahan, jangan dihadapi dengan kemarahan yang keras. Percuma, perilaku itu tidak akan membuatnya patuh justru wanita akan semakin memberontak dan sedih.

Dari Abu Hurairah Radhiyallahu 'anhu, Rasulullah Shalallahu 'alayhi Wasallam bersabda: "Berbuat baiklah kepada Wanita, karena sesungguhnya mereka diciptakan dari Tulang Rusuk, dan sesungguhnya Tulang Rusuk yang paling bengkok adalah yang paling atas. Maka sikapilah para Wanita dengan baik." (HR al- Bukhari)

Hanya karena kedudukan suami sebagai kepala keluarga, bukan berarti ia bebas membentak dan memukul istrinya. Selama istrinya tidak melakukan dosa yang fatal, sebaiknya suami memaafkan. Karena bagaimanapun juga tidak ada manusia yang sempurna. Jangan hanya diingat buruk-nya saja. Tapi ingatlah juga kebaikankebaikan istri yang telah merawatmu, menghidangkan makanan, mencuci pakaianmu, dan mendidik anak-anakmu. Lalu bagaimana jika istri berbuat dosa yang melanggar syariat agama (seperti berselingkuh), Allah SWT telah menjelaskan jawabannya dalam surat An-nisa ayat 34 yang artinya: "...Wanita-wanita yang kalian khawatirkan nusyuznya, maka nasihatilah mereka, dan jauhilah mereka di tempat tidur, dan pukullah mereka. Jika mereka menaati kalian, janganlah kalian mencari-cari jalan untuk menyusahkan mereka. Sesungguhnya Allah Mahatinggi lagi Mahabesar." (QS. An-nisa: 34)

Dari ayat diatas, ada 3 hal yang boleh dilakukan suami saat ia merasa diperlakukan tak adil oleh istrinya:

- Menasihati istri dengan tutur kata yang baik.

- Apabila istri tidak bisa dinasehati, maka suami boleh mendiamkannya (pisah ranjang).

- Jika masih tidak digubris, barulah suami boleh memukul istrinya dengan syarat pukulan itu tidak boleh menimbulkan cedera, tidak boleh memukul diwajah. Tidak boleh memukul dengan tongkat dan benda lain yang keras. Pukulan cukup dilakukan dengan tangan dan tidak untuk menyakiti. Melainkan hanya sebagai pelajaran. Perlu diingat bahwa pukulan ini menjadi opsi terakhir apabila istri benar-benar tidak bisa intropeksi diri. Karena bagaimanapun juga Rasulullah Saw juga tidak menyukai laki-laki yang berbuat kasar, sebagaimana sabdanya: "Apakah pantas, salah seorang di antara kalian memukul istrinya seperti seorang budak tetapi kemudian menggaulinya di penghujung malam?"

Allah SWT menganjurkan seorang suami untuk bersabar menghadapi istrinya, sebagaimana firmannya: "Hai orang-orang yang beriman, tidak halal bagi kamu mempusakai wanita dengan jalan paksa dan janganlah kamu menyusahkan mereka karena hendak mengambil kembali sebagian dari apa yang telah kamu berikan kepadanya, terkecuali bila mereka melakukan pekerjaan keji yang nyata. Dan bergaullah dengan mereka secara patut. Kemudian bila kamu tidak menyukai mereka, (maka bersabarlah) karena mungkin kamu tidak menyukai sesuatu, padahal Allah menjadikan padanya kebaikan yang banyak." (Q.S.al-Nisa: 19).

Dengan demikian, dapat disimpulkan bahwa hukum menyakiti hati wanita tidak boleh. Suami wajib memperlakukan istrinya dengan baik kecuali si istri melakukan perbuatan sangat keji. 
Sejak Islam datang ke dunia, citra dan kedudukan wanita dalam masyarakat mulai mengalami kemajuan. Allah memerintahkan kepada seluruh umat manusia agar senantiasa bersikap baik pada wanita, sebagaimana firman Allah SWT berikut ini : "Dan perlakukanlah mereka secara patut, kemudia bila kamu tidak menyukai mereka (maka bersabarlah) karena mungkin kamu tidak menyukai sesuatu, padahal Allah menjadikan padanya kebaikan". (An-Nisa': 19).

Citra adalah gambaran yang dimiliki orang banyak mengenai pribadi (KBBI,1991: 192). Merujuk pada definisi di atas, yang dimaksud citra dalam penelitian ini adalah gambaran yang dimiliki orang banyak terhadap perempuan sebagai ibu orang Jepang yang berperan sebagai dasar kekuatan negara. Untuk menjadi peran tersebut seorang perempuan sebagai ibu harus memiliki karakter kuat, tajam, ulet, teliti, berwibawa atau berpengaruh, penyayang, berpenampilan rapi, dan sederhana. Selain itu harus berbudi bahasa yang sopan dan tidak langsung (Ide, 1977: 15). Di dalam Al-Qur' an surat Al-Ahzab ayat 35 Allah Swt berfirman: "Sesungguhnya laki-laki dan perempuan yang muslim, laki-laki dan perempuan yang mukmin, laki-laki dan perempuan yang tetap dalam ketaatannya, laki-laki dan perempuan yang benar, laki-laki dan perempuan yang sabar, laki-laki dan perempuan yang khusyu, laki-laki dan perempuan yang bersedekah, laki-laki dan perempuan yang berpuasa, laki-laki dan perempuan yang menjaga kehormatannya, laki-laki dan perempuan yang menyebut (nama) Allah, Allah telah menyediakan untu mereka ampunan dan pahala yang besar."

Al-Qur'an memberikan citra yang amat positif terhadap wanita. Hal ini dapat dilihat pada uraian al-Quran tentang asal-usul dan reproduksi manusia. Al-Quran sama sekali tidak pernah memberikan isyarat-isyarat diskriminatif terhadap kaum wanita. Islam adalah rahmat bagi seluruh alam dan meski kita mengetahui bahwa wanita diciptakan dari tulang rusuk laki-laki, namun Islam tidak pernah menyatakan bahwa derajat wanita di bawah laki-laki. Allah berfirman dalam surah Al-Ahzab ayat 35 yang artinya :"Sesungguhnya laki-laki dan perempuan muslim, laki-laki dan perempuan mukmin, laki-laki dan perempuan yang tetap dalam ketaatannya, laki-laki dan perempuan yang benar, laki-laki dan perempuan yang sabar, laki-laki dan perempuan yang khusuk, lakilaki dan perempuan yang bersedekah, laki-laki dan perempuan yang berpuasa, laki-laki dan perempuan yang memelihara kehormatannya, laki-laki dan perempuan yang banyak menyebut (nama) Allah, Allah telah menyediakan untuk mereka ampunan dan pahala yang besar".

Dalam sebuah hadits yang diriwayatkan oleh Abd bin Humaid, Ath-Thabari, dan At-Tirmidzi bahwa Ummu Imarah Al-Anshariyah, pernah menemui Rasulullah dan berkata: "Kulihat semua diperuntukkan bagi laki-laki, kulihat tak sekalipun perempuan disebut". Lalu turunlah ayat ini. Ibnu Abbas berkata, "Beberapa perempuan menemui Rasulullah seraya berkata; 'Wahai rasulullah kenapa laki-laki yang beriman selalu disebut, sedangkan perempuan yang beriman tidak disebut?', dan kemudian ayat ini diturunkan untuk menjawab pertanyaan tersebut.

Bersamaan dengan turunnya ayat tersebut Allah menyatakan bahwa dalam pandangan Islam, kedudukan wanita sama saja dengan kedudukan laki-laki dalam hal ibadah dan iman yang dimilikinya. Baik laki-laki maupun perempuan memiliki kesempatan yang sama untuk mencapai derajat keimanan dan keislaman yang tertinggi. Mereka berhak mendapatkan pahala dan ganjaran serta ampunan Allah jika mereka berbuat dosa. Dan yang paling penting, kedudukan wanita juga sama dalam hal kesempatan mendapatkan pahala, surga, dan kenikmatan di akhirat apabila mereka beriman, taat dan rajin melakukan amal saleh. 


\section{PENUTUP}

Dalam masyarakat Jepang perempuan (onna) memiliki dua sisi, yaitu sebagai onna (perempuan) dan di sisi lain onna (perempuan) sebagai ibu. Perempuan sebagai ibu berperan sebagai pendidik anak sebagai generasi penerus bangsa. Sehingga berperan sebagai "kyouiku mama" (ibu pendidik). Baik-buruknya anak atau generasi penerus bangsa salah satunya ditentukan oleh ibu sebagai pendidiknya. Ibu yang menghasilkan generasi yang baik dapat menjadikan negara yang baik dan kuat. Begitu pula sebaliknya.

Dalam setiap adat dan budaya apalagi budaya Jepang yang notabene bukan mayoritas penganut agama Islam tentu banyak norma-norma yang diluar pandangan dan ajaran Islam, namun daripada itu terdapat juga kesamaan dan keserasian dalam hal-hal tertentu misalnya tentang karakter perempuan yang menyatakan bahwa perempuan itu harus taat pada aturan, perempuan harus kuat dan beberapa hal yang harus menjadi perhatian mengenai penampilan seorang perempuan bagi adat budaya Jepang dan menurut pandangan Islam.

Islam sebagai sebuah ajaran memposisikan perempuan pada tempat yang mulia, kedudukan perempuan sama saja dengan kedudukan laki-laki dalam hal ibadah dan iman yang dimilikinya. Baik laki-laki maupun perempuan memiliki kesempatan yang sama untuk mencapai derajat keimanan dan keislaman yang tertinggi. Mereka berhak mendapatkan pahala dan ganjaran serta ampunan Allah jika mereka berbuat dosa. Dan yang paling penting, kedudukan wanita juga sama dalam hal kesempatan mendapatkan pahala, surga, dan kenikmatan di akhirat apabila mereka beriman, taat dan rajin melakukan amal saleh.

\section{DAFTAR PUSTAKA}

Al-Qur'an Tajwid Warna Al-Mu'asir.Cetakan III: Muharram 1438/ Oktober 2016. Bandung: Khazanah Intelektual.

Al-Syaikh., Badwi. 2010. 100 Pesan Nabi untuk Wanita. Bandung: Mizania.

Ash-Shiddiqie, Hasbi. 1975. Filsafat Hukum Islam, CV Bulan Bintang, Jakarta

Al-Shabuni, Muhammad Ali. 1971. Rawai' al-Bayan Fi Tafsir Ayat al-Ahkam, Jl. I, Dar al-Fikr, Beirut.

Bahri, Andi. 2015. "Perempuan dalam Islam". Jurnal Nasional Al-Maiyyah Volume 8 No. 2.

Barker, Chris. 1999. Cultural Studies: Teori dan Praktik. Yogyakarta: Bentang.

Benedict, Ruth.1979. The Chrysanthemum and the Sword. Tokyo: Charles E. Tuttle Company.

Hanapi, Agustin. 2015. Peran Perempan Dalam Islam. Internasional Journal of Child and Gender Studies: Gender Equality Vol. 1, No. 1.

Hutcheon, Linda. 2004. Politik Posmodernisme. Yogyakarta: Jendela.

Ide, Sachiko. 1997. Joseigo no Sekai. Tokyo: Meiji Shoin.

Khallaf, Muhammad Abdul Wahab. 1978. Ilmu Ushul al Figh, Cet. XII, Dar al-Qalam, Beirut.

Nurdianti, Siti Zahro. 2015. “Wanita dalam Perspektif Islam”. tahdits.wordpress.com 
Piliang, Yasraf. 2003. Hipersemiotika: Tafsir Cultural Studies atas Matinya Makna". Yogyakarta: Jalasutra.

Ridha, Muhammad Rasyid. 1367 H. Tafsir Al-Manar, Jilid IV, Dar al-Fikr, Kairo.

Sabiq, Sayid. 1983. Fiqh al-Sunnah, Juz II. Dar al-Fikr, Beirut.

Shihab, H. Muhammad Quraish. 1995. Membumikan Alquran, Cet.I. Mizan, Bandung.

Sunarni, Nani. Johana, Jonjon. 2017. Citra Perempuan dan Pria dalam Budaya Jepang". Bandung: Balatin Pratama.

Yafi, Ali. 1994. Menggagas Fiqih Sosial, Cet. I, Mizan Bandung.

Tim penerjemah Depag RI. tt. Alquran dan Terjemahannya, Khadim Al-Haramain, Saudi Arabia.

\section{Kamus}

Badan Bahasa. 1995. Kamus Besar Bahasa Indonesia. Jakarta.

Tanaka, Yoshinobu et.al. 1990. Kouji Kotowaza no Jiten. Tokyo: Shougakukan.

Toudou, Akiyasu. 1987. Gakushuu Kanji Jiten. Tokyo: Shougaku 